\title{
Analisis Daya Saing Ekspor Udang Indonesia ke Delapan Negara Tujuan Terbesar Tahun 2000-2019
} \author{
Countries 2000-2019) \\ Fath Esa Prasanti Kusuma ${ }^{1 *}$, Liza Kurnia Sari² \\ 1,2Politeknik Statistika STIS \\ Jl. Otto Iskandardinata No. 64C Jakarta Timur 13330 \\ E-mail: 211709687@stis.ac.id
}

(Analysis of Competitiveness on Indonesian Shrimp Export to the Eight Biggest Destination

\begin{abstract}
ABSTRAK
Menurut data UN Comtrade pada tahun 2019 delapan negara tujuan ekspor komoditas udang Indonesia terbesar mampu menyerap lebih dari 90 persen ekspor komoditas udang Indonesia. Namun, kontribusi ekspor udang Indonesia masih rendah dalam memenuhi kebutuhan udang impor negara importir. Oleh karena itu, penelitian ini bertujuan untuk mengetahui daya saing serta faktor-faktor yang memengaruhi ekspor udang Indonesia. Data yang digunakan merupakan data panel dengan observasi sebanyak 8 negara selama periode 2000-2019. Penelitian ini menggunakan metode analisis RCA dan regresi data panel dengan pendekatan gravity model. Variabel dependen yang digunakan adalah volume ekspor udang. Sedangkan variabel independen yang digunakan adalah harga riil ekspor udang, REER, populasi negara tujuan, jarak ekonomi, dan PDB ADHK negara tujuan. Diperoleh hasil bahwa daya saing udang Indonesia di atas rata-rata dunia kecuali di Thailand. Selain itu, variabel real effective exchange rate (REER), harga riil ekspor udang, dan jarak ekonomi memiliki pengaruh negatif signifikan terhadap volume ekspor udang Indonesia ke delapan negara terbesar.
\end{abstract}

Kata kunci: udang, ekspor, daya saing, regresi data panel, model gravitasi

\begin{abstract}
According to Un Comtrade data in 2019, the eight largest shrimp export destinations absorbed more than 90 percent of Indonesian's shrimp. However, the contribution of Indonesian shrimp to these eight countries is still low. Therefore, this research was conducted to determine the competitiveness and the factors that influence Indonesian shrimp exports. This research used panel data of 8 largest destination countries during 2000-2019. Analysis method that used is RCA analysis and panel data regression with a gravity model approach. Dependent variable in this research is volume of shrimp exports. While the independent variable are real export prices, REER, population of destination countries, GDP constant of destination countries, and economic distances. The results show that Indonesian shrimp have competitiveness above the world average except in Thailand. In addition, it was found that economic distance, REER, and price had a significant effect on Indonesia's shrimp exports to the eight biggest destinations
\end{abstract}

Keywords: shrimps, export, competitiveness, data panel regression, gravity model

\section{PENDAHULUAN}

Indonesia sebagai negara kepulauan terbesar dengan luas perairan tiga per empat dari seluruh wilayahnya diperkirakan memiliki potensi sumber daya ikan laut lebih dari 12 juta ton per tahun (KKP, 2018). Selain diperdagangkan di dalam negeri, hasil kelautan dan perikanan Indonesia juga diperdagangkan di luar negeri. Menurut data KKP, selama tahun 2015-2019 komoditas udang memberikan kontribusi terbesar terhadap ekspor sektor perikanan. Berdasarkan data UN Comtrade, Indonesia sebagai eksportir udang berada di urutan ke empat, yaitu di bawah India, Ekuador, dan Vietnam. Pada tahun 2019 delapan negara tujuan ekspor udang Indonesia terbesar, yaitu Amerika Serikat, Belanda, Malaysia, Thailand Jepang, Cina, Britania Raya, dan Singapura, mampu menyerap lebih dari 90 persen ekspor udang Indonesia. 


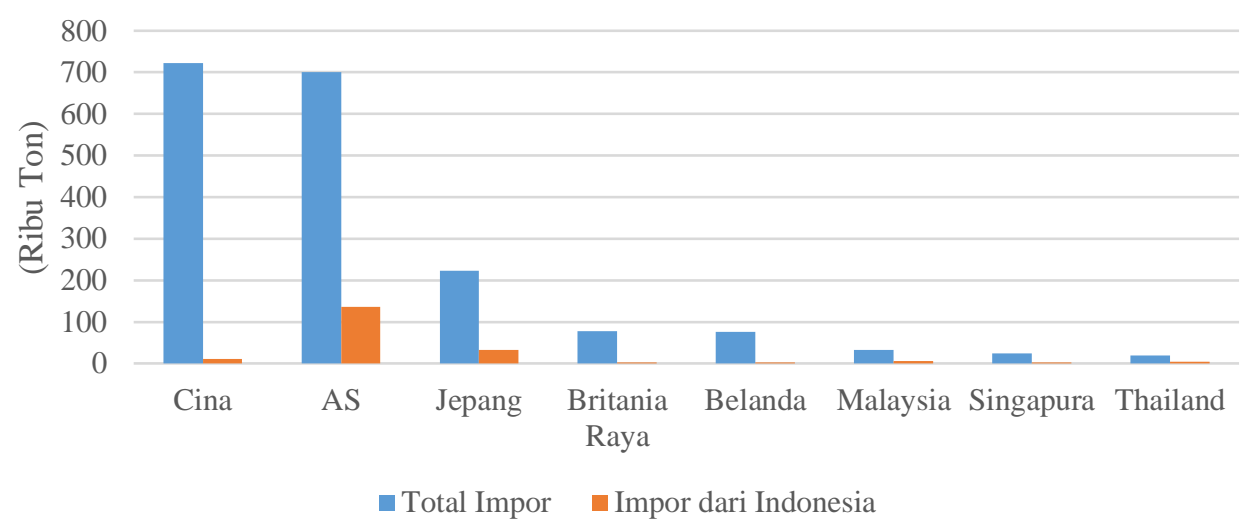

Sumber: UN Comtrade (diolah)

Gambar 1. Perbandingan Impor Udang dari Indonesia dan Dunia pada Delapan Negara Tujuan 2019

Gambar 1 menunjukkan bahwa kontribusi ekspor Indonesia dalam memenuhi kebutuhan ke delapan negara tersebut masih rendah. Peranan Indonesia dalam memenuhi kebutuhan impor udang terbesar terjadi di Amerika Serikat dengan kontribusi sebesar 19,14 persen dari 700,89 ribu ton. Sedangkan kontribusi terkecil terjadi di Cina. Cina mengimpor udang sekitar 722 ribu ton, namun Indonesia hanya mampu memenuhi 1,42 persen dari kebutuhan tersebut. Belum optimalnya kontribusi ekspor udang Indonesia dalam mencukupi kebutuhan udang negara importir menunjukkan adanya peluang bagi Indonesia untuk meningkatkan ekspor udangnya.

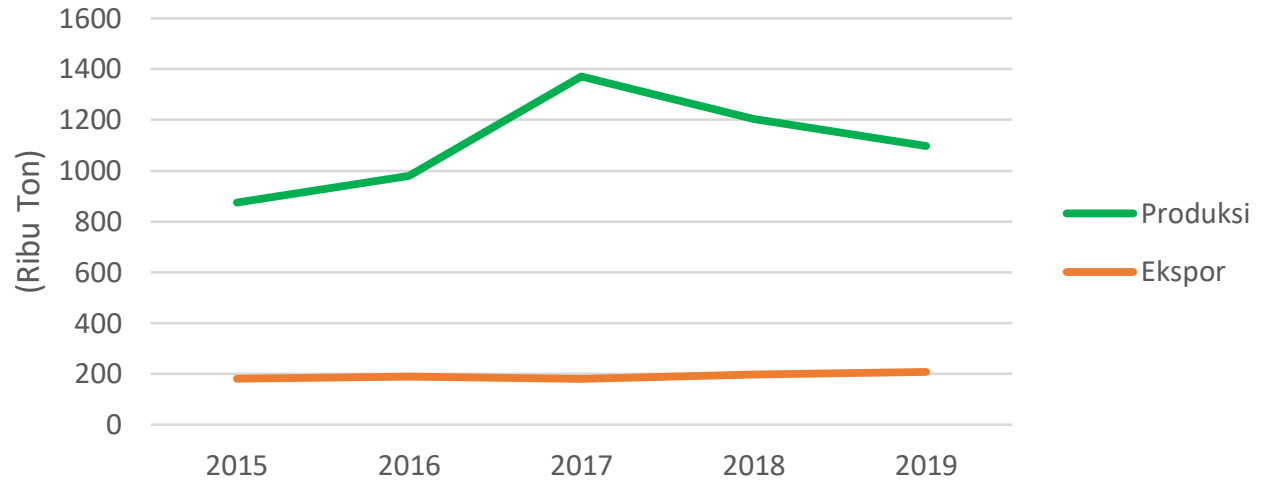

Sumber: UN Comtrade dan KKP (diolah)

Gambar 2. Volume Ekspor dan Produksi Udang Indonesia

Gambar 2 menunjukkan bahwa perbedaan antara produksi dan ekspor udang yang besar. Selama lima tahun terakhir, rata-rata ekspor udang hanya sekitar 17 persen dari total produksinya. Hal ini mengindikasikan bahwa Indonesia juga memiliki kesempatan untuk menambah ekspor udangnya.

Menurut Wahyudi et al. (2019) variabel nilai tukar rupiah, PDB nominal negara tujuan, dan nilai ekspor udang Indonesia tahun sebelumnya berpengaruh signifikan positif dan variabel jarak ekonomi berpengaruh signifikan negatif terhadap nilai ekspor udang Indonesia di negara tujuan dengan metode analisis regresi data panel pendekatan model gravity.

Penelitian lain yang dilakukan oleh Mitayani (2018) dengan metode analisis regresi data panel (FEM) disimpulkan bahwa variabel PDB dan nilai tukar mata uang negara tujuan memengaruhi permintaan udang Indonesia secara positif signifikan. Sedangkan variabel harga udang memiliki pengaruh negatif signifikan.

Penelitian lain oleh Mashari et al. (2019) memberikan hasil bahwa udang beku dan olahan Indonesia berdaya saing kuat di pasar internasional. Pada periode 2007-2017 udang olahan mengalami falling star sedangkan udang beku Indonesia berada di posisi lost opportunity. Sementara pada periode 2012-2017 udang olahan dan beku Indonesia mencapai kondisi terbaik yakni rising star. Metode analisis yang digunakan adalah Revealed Competitive Advantage (RCA) dan Dynamic Revealed Comparative Advantage (DRCA).

Sedangkan menurut Ashari et al., (2016) daya saing udang beku Indonesia masih lebih tinggi dibandingkan dengan udang segar. Dalam jangka pendek, faktor-faktor yang memengaruhi signifikan positif daya saing ekspor udang beku Indonesia ke Amerika Serikat adalah tingkat daya saing ekspor udang beku Indonesia ke Amerika Serikat periode sebelumnya, produksi udang beku Indonesia, dan harga ekspor udang beku Vietnam. Dalam jangka panjang, PDB Amerika Serikat, daya saing ekspor udang beku Indonesia ke Amerika Serikat pada periode sebelumnya, dan produksi udang beku Indonesia yang memengaruhi secara 
signifikan positif. Dalam jangka pendek, faktor-faktor yang berpengaruh signifikan positif terhadap daya saing ekspor udang segar Indonesia ke Malaysia adalah total produksi udang segar Indonesia. Dalam jangka panjang, tingkat daya saing udang segar Indonesia periode sebelumnya berpengaruh signifikan positif dan PDB Indonesia secara signifikan negatif terhadap daya saing ekspor udang segar Indonesia ke Malaysia. Metode yang digunakan adalah Revealed Comparative Advantage (RCA) dan Error Correction Model (ECM).

Pada penelitian ini, diduga variabel harga riil, REER, dan jarak ekonomi memiliki pengaruh negatif terhadap volume ekspor udang Indonesia. Sedangkan variabel PDB ADHK dan populasi negara tujuan diduga berpengaruh positif.

Permasalahan pada penelitian ini adalah rendahnya kontribusi ekspor udang Indonesia dalam memenuhi kebutuhan udang impor negara importir, sedangkan di sisi lain masih terdapat perbedaan yang besar antara ekspor dan produksi udang Indonesia. Hal ini menunjukkan bahwa Indonesia masih memungkinkan untuk meningkatkan ekspornya. Oleh karena itu, perlu dilakukan analisis lebih lanjut mengenai daya saing ekspor udang Indonesia terhadap 8 negara tujuan terbesar serta faktor-faktor yang mempengaruhinya. Di mana ke delapan negara ini mampu menyerap lebih dari 90 persen ekspor udang Indonesia. Tujuan dari penelitian ini adalah untuk mengetahui perkembangan ekspor dan daya saing udang Indonesia serta faktor-faktor yang memengaruhi ekspor udang Indonesia. Berbeda dengan penelitian terdahulu, penelitian ini berfokus pada delapan negara tujuan ekspor udang Indonesia terbesar. Selain itu, proxy variable nilai tukar yang digunakan adalah REER. Diharapkan dengan demikian penelitian ini dapat menambah informasi mengenai ekspor udang Indonesia.

\section{METODE}

\section{Landasan Teori}

Udang adalah salah satu spesies dari sub ordo Natantia (ordo Decapoda dari kelas Crustacea) (Britannica, 2004). Udang memiliki badan semi transparan yang diratakan dari sisi ke sisi dan perut fleksibel yang ujungnya berbentuk seperti kipas. Salah satu hasil perikanan yang banyak diperjual-belikan di pasar internasional adalah udang. Bentuk produk udang yang dipasarkan ke pasar internasional cukup beragam. Jenis yang dipasarkan pada umumnya berupa udang segar dingin, udang beku, dan udang kaleng.

Perdagangan internasional merupakan interaksi jual-beli penduduk suatu negara dengan penduduk di negara lain yang dilakukan atas dasar kesepakatan bersama. Perdagangan internasional merupakan kegiatan ekonomi antar negara untuk memenuhi kebutuhan penduduk dengan melakukan pertukaran barang maupun jasa. Pertukaran barang atau jasa antar negara terjadi akibat adanya perbedaan permintaan dan penawaran yang bersaing. Terdapat dua teori mengenai perdagangan internasional yaitu teori keunggulan absolut dan keunggulan komparatif. Berdasarkan teori keunggulan absolut, perdagangan internasional tidak dapat terjadi jika suatu negara tidak miliki keunggulan absolut. Sedangkan berdasar teori keunggulan komparatif, selama harga komparatif kedua negara berbeda, meskipun salah satu negara tidak memiliki keunggulan absolut, perdagangan internasional dapat terjadi (Salvatore, 2013).

Ekspor dan impor merupakan aktivitas perdagangan di pasar internasional. Impor adalah kegiatan membeli barang dan jasa yang diproduksi di luar negeri untuk domestik, sedangkan ekspor adalah kegiatan menjual barang dan jasa yang diproduksi dalam negeri ke luar negeri (Mankiw, 2017). Ekspor neto adalah nilai ekspor negara terkait dikurangi dengan nilai impornya. Terdapat banyak faktor yang mempengaruhi ekspor, impor, dan ekspor neto suatu negara. Faktor-faktor tersebut adalah sebagai berikut:

1) Selera konsumen

2) Harga barang di dalam negeri dan luar negeri

3) Nilai tukar

4) Pendapatan konsumen di dalam dan luar negeri

5) Biaya transportasi barang dari suatu negara ke negara lain

6) Kebijakan pemerintah terhadap perdagangan internasional

Real Effective Exchange Rate (REER) adalah ukuran nilai mata uang sebuah negara terhadap rata-rata tertimbang beberapa mata uang asing yang dibagi dengan deflator harga atau indeks biaya. Peningkatan REER menyebabkan harga impor menjadi lebih murah dan harga ekspor menjadi lebih mahal (IMF, 2019). Oleh karena itu, peningkatan REER menunjukkan hilangnya daya saing perdagangan.

Pindyck \& Rubinfeld (2013) menyebutkan bahwa harga nominal suatu barang adalah harga absolutnya. Sedangkan harga riil dari suatu barang adalah harga relatif terhadap ukuran harga agregat. Dengan kata lain, harga riil adalah harga yang disesuaikan dengan inflasi. Harga riil diperoleh dengan menggunakan rumus sebagai berikut (Pindyck \& Rubinfeld (2013): 
$\operatorname{Hrg} \operatorname{Riil}_{t}=\operatorname{Harga}_{t} \times \frac{\mathrm{IHK}_{\mathrm{t} 0}}{I H K_{t}}$ dimana:

$t \quad=$ Tahun berjalan

$t_{0} \quad=$ Tahun dasar

Hrg Riil = Harga riil

Harga $=$ Harga nominal

IHK = Indeks harga konsumen

Penurunan tingkat harga akan meningkatkan nilai riil mata uang dan membuat konsumen lebih kaya, sehingga mendorong konsumen untuk membelanjakan lebih banyak (Mankiw, 2017). Peningkatan belanja konsumen meningkatkan barang dan jasa yang diminta.

PDB merupakan total pendapatan yang diperoleh di dalam negeri, mencakup pendapatan yang dihasilkan dari faktor-faktor produksi milik asing dan total pengeluaran untuk barang dan jasa yang dihasilkan di dalam negeri (Mankiw, 2016). PDB berbanding lurus terhadap perdagangan di suatu negara (Krugman et al., 2018).

Populasi adalah seluruh jumlah penduduk yang menempati suatu wilayah (seperti negara atau dunia) dan terus-menerus berubah karena adanya oleh peningkatan dan penurunan (Teitelbaum, 2020). Perubahan populasi suatu negara memengaruhi jumlah perdagangan dari sisi permintaan maupun penawaran. Pada sisi permintaan berpengaruh pada perubahan jumlah permintaan suatu komoditas tertentu (Salvatore, 2013). Sedangkan pada sisi penawaran, berpengaruh pada perubahan jumlah tenaga kerja.

Daya saing internasional diartikan sebagai kemampuan sebuah negara atau perusahaan untuk menghasilkan lebih banyak kekayaan bagi rakyatnya daripada pesaingnya di pasar dunia (Salvatore, 2013). Suatu negara yang mampu memproduksi barang atau jasa dengan biaya lebih rendah dapat memperoleh keuntungan pada harga-harga yang terjadi di pasar internasional. Efisien tidaknya kegiatan produksi suatu komoditas yang dapat diperdagangkan bergantung pada daya saingnya di pasar dunia.

Model gravitasi perdagangan dunia adalah persamaan yang menyatakan volume perdagangan antara dua negara (Krugman et al., 2018). Dinamakan model gravitasi perdagangan karena dianalogikan dengan hukum gravitasi Newton. Sama seperti gaya gravitasi, berbanding terbalik dengan jarak dan sebanding dengan massa benda tersebut. Perdagangan antara dua negara erbanding terbalik dengan jarak dan berbanding lurus dengan PDB. Model gravitasi perdagangan dapat dinyatakan dalam persamaan berikut (Krugman et al., 2018):

$$
T_{i j}=A \times Y_{i}^{\beta_{1}} \times \frac{Y_{j}^{\beta_{2}}}{D_{i j}^{\beta_{3}}}
$$

dimana:

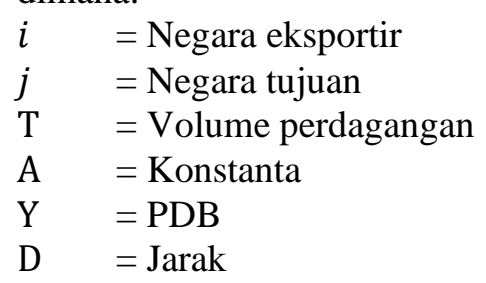

Persamaan 1 dimodifikasi ke dalam bentuk log linier agar dapat digunakan untuk model regresi, sehingga diperoleh persamaan baru sebagai berikut:

$$
\ln \left(T_{i j}\right)=A+\beta_{1} \ln \left(Y_{i}\right)+\beta_{2} \ln \left(Y_{j}\right)-\beta_{3} \ln \left(D_{i j}\right)
$$

Jarak antara dua negara merupakan faktor penting dalam perdagangan secara geografis. Jarak mencerminkan biaya transportasi (Krugman et al., 2018). Semakin besar maka biaya transportasi perdagangan semakin besar. Variabel jarak didekati dengan variabel jarak ekonomi yang telah dibobotkan. Adapun rumus jarak ekonomi dapat dinyatakan sebagai berikut (Li et al., 2008):

$$
D I S T_{i j}=\frac{\left(D_{i j} \times P D B_{j}\right)}{\sum_{1}^{n} P D B_{j}}
$$

dimana:

$\begin{array}{ll}i & =\text { Negara eksportir } \\ j & =\text { Negara tujuan } \\ \mathrm{n} & =\text { Jumlah negara tujuan ekspor } \\ D I S T & =\text { Jarak ekonomi } \\ D & =\text { Jarak fisik } \\ P D B & =\text { PDB }\end{array}$




\section{Data dan Sumber Data}

Pada penelitian ini digunakan data panel yang bersumber dari Badan Pusat Statistik (BPS), Kementerian Kelautan dan Perikanan, Centre d'Etudes Prospectives et d'Informations Internationales (CEPII), UN Comtrade, dan World Bank. Periode tahun yang digunakan mulai dari tahun 2000 hingga tahun 2019 dengan observasi 8 negara tujuan ekspor terbesar pada tahun 2019, yaitu Amerika Serikat, Jepang, Cina, Malaysia, Thailand, Belanda, Britania Raya, dan Singapura.

Variabel yang digunakan dalam analisis RCA adalah nilai ekspor udang Indonesia, total nilai ekspor Indonesia, nilai ekspor udang dunia, dan total nilai ekspor dunia ke negara tujuan. Sedangkan variabel yang digunakan dalam analisis regresi data panel adalah volume ekspor udang ke negara tujuan, harga riil ekspor udang, PDB ADHK negara tujuan, Real Effective Exchange Rate (REER), dan jarak ekonomi. Komoditas udang yang tercakup adalah komoditas udang dengan enam digit kode Harmonized Sytem (HS) 2012, yaitu 030616, 030617, 030626, 030627, 160521, dan 160529.

\section{Metode Analisis Data}

Metode analisis regresi data panel dan indeks Revealed Comparative Advantage (RCA) digunakan dalam penelitian ini. Analisis RCA dilakukan untuk mengukur keunggulan komparatif (daya saing) komoditas udang Indonesia di delapan negara tujuan ekspor terbesar (Kementrian Perdagangan Republik Indonesia). Dengan menggunakan metode RCA, tingkat daya saing dapat diperbandingkan tiap tahunnya. Rumus RCA adalah sebagai berikut:

$$
R C A=\frac{\frac{x_{i j}}{X_{i t}}}{\frac{W_{i j}}{W_{i t}}}
$$

Dimana:

$X_{i j} \quad=$ Nilai ekspor udang Indonesia

$X_{i t} \quad=$ Nilai total ekspor Indonesia

$W_{i j} \quad=$ Nilai ekspor udang dunia

$W_{i t} \quad=$ Nilai total ekspor dunia

Apabila nilai indeks RCA lebih dari satu berarti bahwa negara terkait memiliki daya saing di atas ratarata dunia untuk komoditi tersebut dan sebaliknya.

Analisis regresi data panel dengan pendekatan model gravity digunakan untuk menentukan variabel yang mempengaruhi ekspor udang Indonesia ke delapan negara tujuan terbesar. Terdapat tiga kemungkinan model pada regresi data panel (Greene, 2012). Model tersebut antara lain adalah model common effect (CEM), model fixed effect (FEM), dan model random effect (REM).

Berikut tahapan analisis regresi data panel:

1. Menentukan variabel dependen dan variabel independen.

2. Melakukan uji stasioneritas data. Akan tetapi pada penelitian ini tidak dilakukan karena jumlah individu dan periode waktu tidak masuk dalam rentang jika jumlah individu antara 10 hingga 250 dan jumlah periode waktu (T) antara 25 hingga 250 Baltagi (2005).

3. Membentuk ketiga model.

4. Menentukan model terbaik berdasarkan hasil uji formal, yaitu uji Chow, Hausman, dan BP-LM (Baltagi, 2011). Uji Chow dilakukan untuk memilih antara CEM dan FEM. Uji BP-LM digunakan untuk memilih antara REM dan CEM.. Sedangkan uji Hausman dilakukan untuk memilih antara FEM dan REM.

5. Apabila terpilih model FEM, maka dilakukan pemeriksaan terhadap struktur varians-kovarians residual, yaitu dengan uji LM dan $\lambda \mathrm{LM}$. Uji LM digunakan untuk mengetahui ada tidaknya heteroskedastik. Sementara itu, uji digunakan untuk mengetahui ada tidaknya cross sectional correlation.

6. Melakukan pengujian asumsi klasik. Asumsi klasik harus terpenuhi untuk memperoleh model dengan estimator yang bersifat BLUE (Best Linear Unbiased Estimator). Pada metode OLS asumsi klasik yang perlu dipenuhi adalah asumsi normalitas, homoskedasitas, non-autokorelasi, dan non-multikolinieritas. Sedangkan pada metode estimasi GLS/ FGLS, maka asumsi klasik yang harus dipenuhi normalitas dan multikolinieritas. Hal ini karena diasumsikan pada metode GLS/ FGLS telah terbebas dari heteroskedasitas dan autokorelasi (Juanda (2009) dan Gujarati \& Porter (2009)).

7. Melakukan pengujian keberartian model dengan menggunakan koefisien determinasi, uji t, dan uji $F$. Pengujian simultan (uji F) digunakan untuk mengetahui keberartian variabel independen dalam model regresi yang digunakan secara bersamaan (Gujarati \& Porter, 2009). Sedangkan uji t dilakukan untuk memverifikasi kebenaran atau kesalahan hipotesis nol yang digunakan (Gujarati \& Porter, 2009). 
Sementara koefisien determinasi digunakan untuk menggambarkan kecukupan model regresi yang tepat (Walpole et al., 2016). Sedangkan kecocokan garis regresi sampel dengan data ditunjukkan oleh koefisien determinasi (Gujarati \& Porter, 2009).

8. Melakukan interpretasi hasil estimasi model terbaik.

Berikut adalah persamaan umum regresi data panel dalam penelitian ini:

$\ln (\mathrm{Vol})_{i t}=\alpha+\beta_{1} \ln (P D B)_{i t}+\beta_{2} \ln (R E E R)_{i t}+\beta_{3} \ln (J E)_{i t}+\beta_{4} \ln (\text { Harga })_{i t}+\beta_{5} \ln (P o p)_{i t}+u_{i t}(6)$ dimana:

\begin{tabular}{|c|c|}
\hline i & $=$ Negara tujuan ke-i \\
\hline $\mathrm{t}$ & $=$ Tahun ke-t \\
\hline$\alpha$ & $=$ Konstanta \\
\hline$\beta_{1}, \beta_{2}, \beta_{3}, \beta_{4}, \beta_{5}$ & = Koefisien regresi variabel independen \\
\hline $\begin{array}{l}\text { Vol } \\
\text { PDB }\end{array}$ & $\begin{array}{l}=\text { Volume ekspor udang } \\
=\text { PDB ADHK negara tujuan }\end{array}$ \\
\hline REER & $=$ Real Effective Exchange Rate \\
\hline $\mathrm{JE}$ & $=$ Jarak ekonomi \\
\hline Harga & $=$ Harga riil ekspor udang \\
\hline Pop & $=$ Populasi negara tujuan \\
\hline & $=$ Error term \\
\hline
\end{tabular}

\section{HASIL DAN PEMBAHASAN}

\section{Perkembangan Ekspor Udang Indonesia}

Ekspor komoditas perikanan selama tahun 2013-2019 mengalami pertumbuhan positif dengan rata-rata peningkatan nilai ekspor per tahun sebesar 3,89 persen menurut data KKP. Pertumbuhan ekspor perikanan Indonesia memiliki kinerja yang cukup baik. Salah satu hasil perikanan yang memberikan kontribusi besar terhadap ekspor perikanan adalah udang. Komoditas udang mampu memberikan peranan sebesar 34-40 persen terhadap nilai ekspor perikanan Indonesia (Kementrian Kelautan dan Perikanan). Diharapkan ekspor komoditas udang semakin meningkat seiring dengan peningkatan produksinya. Perkembangan ekspor udang Indonesia periode tahun 2000 hingga 2019 mengalami tren meningkat, baik volume maupun nilai ekspor. Perkembangan volume dan ekspor udang Indonesia digambarkan pada Gambar 3 dan Gambar 4 berikut ini.

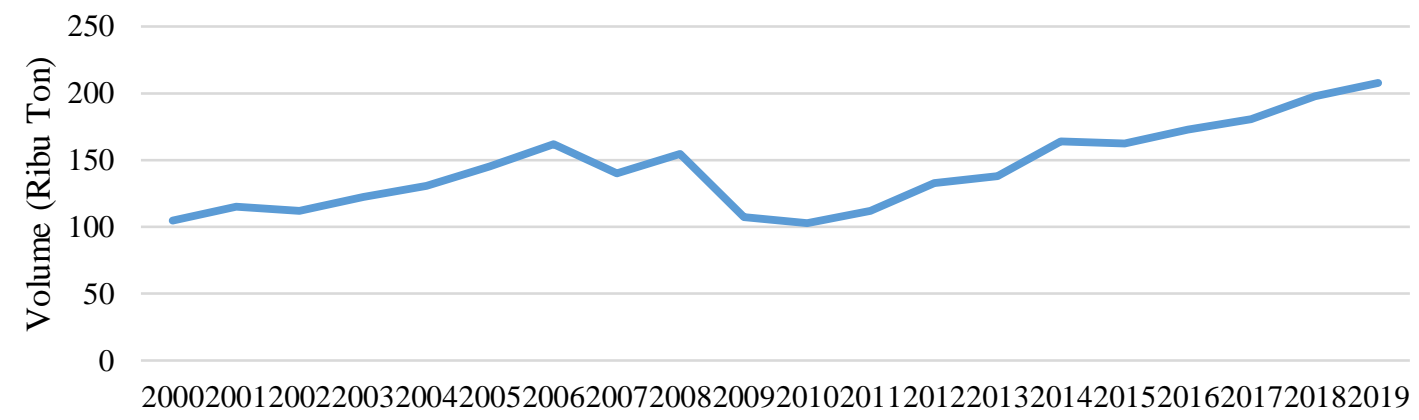

Sumber: BPS

Gambar 3. Volume ekspor udang Indonesia tahun 2000-2019

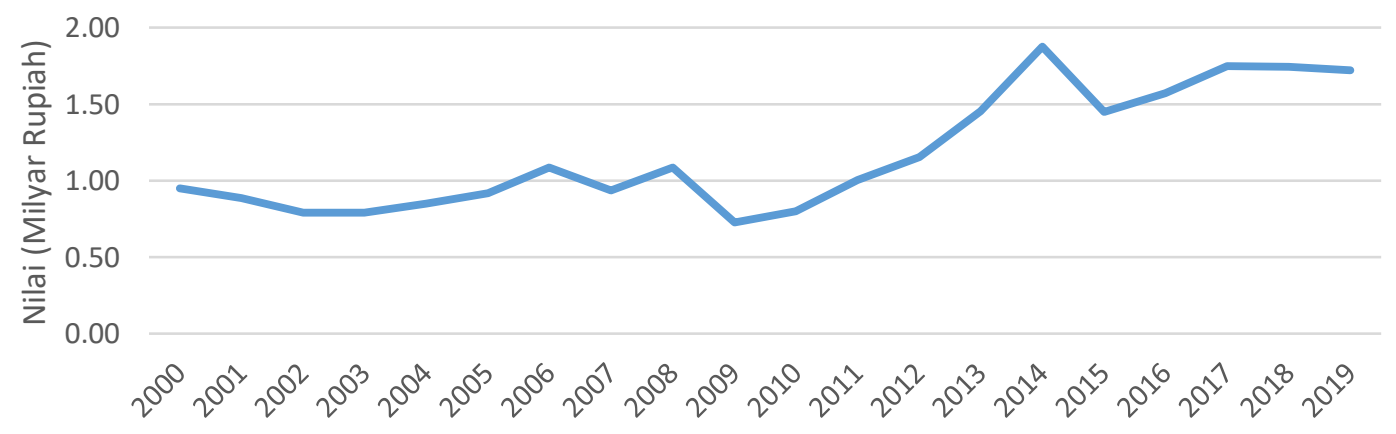

Sumber: BPS

Gambar 4. Nilai ekspor udang Indonesia tahun 2000-2019 
Berdasarkan Gambar 3, volume ekspor udang Indonesia berfluktuatif dan memiliki tren positif. Selama tahun 2000 hingga 2019 rata-rata volume ekspor udang adalah sebesar 143,28 ribu ton. Volume ekspor udang Indonesia terendah terjadi pada tahun 2010, yaitu sebesar 102,81 ribu ton. Setelah tahun 2010, terjadi kenaikan ekspor udang Indonesia hingga 207,75 ribu ton pada tahun 2019.

Gambar 4 menunjukkan total nilai ekspor udang Indonesia. Selama tahun 2000 hingga 2019 rata-rata nilai ekspor udang Indonesia adalah sebesar 1,18 milyar USD. Pada tahun 2014 merupakan tahun dengan nilai ekspor tertinggi, yaitu sebesar 1,88 milyar USD. Pada tahun 2009 terjadi penurunan nilai ekspor udang Indonesia. Penurunan ini terjadi akibat adanya wabah Early Mortality Syndrome (EMS) di Asia yang menyerang udang. Sehingga, importir udang seperti Jepang dan Amerika Serikat mengurangi impor udangnya. Pada tahun 2009 EMS pertama kali ditemukan di Tiongkok, kemudian tahun 2010 di Vietnam, tahun 2011 di Malaysia, dan Thailand tahun 2012 (Handoyo, 2013). Di saat negara produsen udang utama gagal panen akibat EMS seperti Vietnam dan Thailand, Indonesia diuntungkan pada kondisi tersebut. Indonesia mengklaim bahwa udang Indonesia terbebas dari wabah EMS. Sehingga pada tahun 2010 Indonesia mampu meningkatkan nilai ekspor udang kembali meskipun volume ekspor udang Indonesia pada tahun tersebut masih mengalami penurunan. Hal ini dikarenakan harga udang dunia mengalami kenaikan seiring dengan menurunnya pasokan udang dunia. Selain itu, salah satu penyebab penurunan kinerja ekspor udang tahun 2009 ini adalah akibat krisis ekonomi global tahun 2008 yang menyebabkan tingkat permintaan komoditas-komoditas ekspor Indonesia menurun tanpa diiringi peredaman laju impor yang menyebabkan defisit perdagangan (Bappenas, 2009).
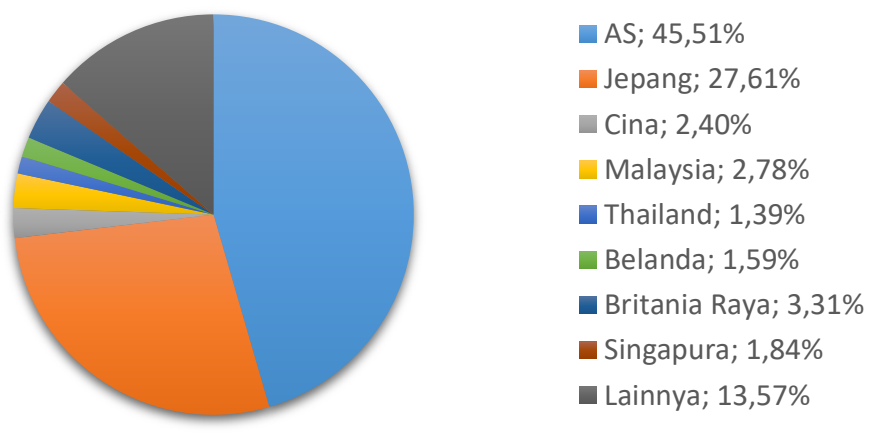

Sumber: Badan Pusat Statistik

Gambar 5. Rata-rata share Volume Ekspor Udang Indonesia tahun 2000-2019

Berdasarkan Gambar 5 diketahui bahwa rata-rata share volume ekspor udang Indonesia paling banyak diserap oleh Amerika serikat, yaitu mencapai 45,51 persen. Pada tahun 2019 Amerika serikat mampu menyerap hampir 65 persen ekspor udang Indonesia. Kemudian pada posisi berikutnya adalah Jepang, Cina, Malaysia, Britania Raya, Belanda, Thailand, dan Singapura. Tujuh negara tersebut menyerap sebanyak sebesar 40,92 persen volume ekspor udang Indonesia. Sedangkan 13,57 persen lainnya diserap oleh negara lain.

\section{Daya Saing Udang Indonesia}

Daya saing suatu komoditas menunjukkan posisi persaingan ekspor dan kekuatan dengan di pasar internasional. Metode RCA dilakukan untuk melihat daya saing ekspor udang Indonesia di delapan negara tujuan terbesar. Berikut adalah tabel indeks RCA di delapan negara tujuan ekspor udang Indonesia terbesar selama 2012 hingga 2019:

Tabel 1. RCA udang Indonesia ke delapan negara tujuan tahun 2012-2019

\begin{tabular}{ccccccccc}
\hline Tahun & $\begin{array}{c}\text { Amerika } \\
\text { Serikat }\end{array}$ & Jepang & Cina & Malaysia & Thailand & Belanda & $\begin{array}{c}\text { Britania } \\
\text { Raya }\end{array}$ & Singapura \\
\hline 2012 & 24,01 & 3,08 & 2,27 & 0,22 & 1,12 & 2,08 & 14,15 & 1,39 \\
2013 & 20,06 & 3,82 & 0,70 & 0,35 & 0,30 & 2,11 & 21,16 & 1,24 \\
2014 & 23,66 & 4,35 & 2,93 & 0,58 & 0,34 & 4,93 & 20,13 & 1,76 \\
2015 & 21,15 & 4,64 & 5,23 & 1,94 & 0,14 & 3,32 & 20,86 & 1,86 \\
2016 & 22,48 & 4,56 & 1,91 & 2,09 & 0,04 & 3,41 & 19,57 & 1,41 \\
2017 & 20,91 & 6,16 & 1,36 & 1,27 & 0,07 & 8,45 & 23,50 & 1,30 \\
2018 & 21,35 & 4,51 & 0,95 & 2,31 & 0,15 & 9,56 & 10,87 & 1,10 \\
2019 & 22,15 & 5,52 & 0,71 & 2,40 & 0,53 & 9,28 & 17,08 & 1,10 \\
Rata-rata & 21,97 & 4,58 & 2,01 & 1,39 & 0,34 & 5,39 & 18,41 & 1,40 \\
\hline
\end{tabular}

Sumber: UN Comtrade dan World Bank (data diolah) 
Berdasarkan Tabel 1, diketahui bahwa indeks RCA di Amerika Serikat lebih tinggi dibandingkan dengan 7 negara lainnya. Rata-rata indeks RCA di Amerika Serikat adalah sebesar 21,97. Hal ini didukung dengan data BPS bahwa volume ekspor udang Indonesia terbesar adalah ke Amerika Serikat. Sedangkan rata-rata indeks RCA udang Indonesia terendah berada di negara Thailand, yaitu sebesar 0,34. Hal ini mengindikasikan bahwa daya saing udang Indonesia di Thailand berada di bawah rata-rata negara pengekspor udang dunia. Menurut data BPS diketahui bahwa tren nilai ekspor udang Indonesia ke Thailand mengalami penurunan yang signifikan dari tahun 2007 hingga 2019.

\section{Faktor-faktor yang Mempengaruhi Ekspor Udang Indonesia}

Analisis regresi data panel dengan pendekatan model gravity dilakukan untuk mengetahui variabel yang memengaruhi ekspor udang Indonesia di delapan negara tujuan terbesar. Model terbaik berdasarkan hasil uji Hausman dan Chow adalah model fixed effect. Setelah dilakukan pengujian LM dan $\lambda$ LM diketahui dalam struktur varian kovarian residual terdapat cross section correlation dan terjadi gejala heteroskedastis. Sehingga metode estimasi yang digunakan adalah model fixed effect with seemingly unrelated regression (SUR). Berdasarkan uji asumsi klasik diketahui bahwa model terpilih mengikuti distribusi normal dan bersifat nonmultikolinieritas. Berikut ini adalah persamaan estimasi yang dihasilkan:

Tabel 2. Fixed Effect Model with SUR

\begin{tabular}{cccc}
\hline Variabel & Koefisien & Std. Error & t-stat. \\
\hline Konstanta & 20,2131 & 2,8045 & $7,2073^{*}$ \\
LN_PDB & 0,0110 & 0,2321 & 0,0475 \\
LN_REER & $-0,7668$ & 0,1758 & $-4,3621^{*}$ \\
LN_JARAK & $-1,1507$ & 0,1485 & $-7,7505^{*}$ \\
LN_HARGA_RIIL & $-0,1872$ & 0,0694 & $-2,6964^{*}$ \\
LN_POPULASI & 0,1985 & 0,6525 & 0,3042 \\
\hline & Ringkasan Statistik & \\
\hline Adj. $R$-squared & 0,9671 & F-Statistik & 389,8720 \\
Durbin Watson & 1,1705 & Prob. F-Statistik & 0,0000 \\
\hline
\end{tabular}

Persamaan regresi data panel yang dihasilkan dapat dituliskan sebagai berikut:

$\ln (\mathrm{Vol})_{i t}=\left(20,2131^{*}+\mu_{i}\right)+0,0110 \ln (P D B)_{i t}-0,7668 \ln (R E E R)^{*}{ }_{i t}-1,1507 \ln (J E)^{*}{ }_{i t}-$

$0,1872 \ln (\text { Harga })_{i t}^{*}+0,1985 \ln (\text { Pop })_{i t}+$

dimana:

* $\quad$ : signifikan pada tingkat signifikansi 5 persen

Nilai adjusted $R$-square pada Tabel 2 sebesar 0,9671 berarti bahwa 96,71 persen variasi volume ekspor udang Indonesia ke delapan negara tujuan terbesar dapat dijelaskan oleh variabel independen dalam model dan sisanya dijelaskan oleh variabel lain yang tidak masuk dalam model.

Berdasarkan nilai probabilitas F statistik pada Tabel 2 dapat disimpulkan bahwa variabel jarak ekonomi, harga riil ekspor udang, populasi, PDB ADHK negara tujuan, dan REER, berpengaruh signifikan secara simultan terhadap volume ekspor udang Indonesia. Sedangkan berdasarkan nilai statistik t pada Tabel 2 dibandingkan dengan $t_{0,05 ; 147}=1,66$ dapat disimpulkan bahwa variabel harga ekspor riil, jarak ekonomi, dan REER berpengaruh negatif signifikan. Sedangkan variabel PDB ADHK dan populasi negara tujuan terhadap volume ekspor udang Indonesia berpengaruh positif tidak signifikan.

Berdasarkan hasil estimasi, variabel harga riil ekspor udang memiliki pengaruh negatif. Nilai koefisien sebesar -0,1872 bermakna bahwa setiap kenaikan 1 persen harga riil ekspor udang, maka rata-rata volume ekspor udang Indonesia ke delapan negara tujuan akan menurun sebesar 0,1872 persen dengan asumsi variabel lain konstan. Hasil estimasi menunjukkan bahwa koefisien harga riil ekspor udang sesuai dengan hipotesis penelitian. Hasil ini sejalan dengan hasil penelitian yang dilakukan oleh Mitayani (2018) bahwa harga memiliki pengaruh negatif terhadap permintaan udang Indonesia di 5 negara tujuan ekspor utama di Asia (jepang, Hong Kong, Tiongkok, Singapura, dan Malaysia). Kenaikan tingkat harga mengurangi nilai riil mata uang, sehingga mengurangi daya beli konsumen (Mankiw, 2017). Semakin rendah harga suatu komoditas, maka permintaan atas komoditas tersebut akan meningkat, sebaliknya jika harga atas suatu komoditas semakin mahal, maka permintaan atas komoditas tersebut akan menurun dengan asumsi hal lainnya tetap.

Koefisien variabel jarak ekonomi pada hasil estimasi menunjukkan bahwa variabel jarak ekonomi memengaruhi volume ekspor udang Indonesia secara negatif. Hal tersebut sesuai dengan hipotesis bahwa jarak 
ekonomi antara Indonesia dan negara tujuan berpengaruh negatif. Hasil ini sejalan dengan penelitian yang dilakukan oleh Wahyudi et al. (2019). Variabel ini memiliki koefisien sebesar -1,1507 yang berarti bahwa setiap penambahan 1 persen jarak ekonomi maka volume ekspor udang Indonesia turun sebesar 1,1507 persen dengan asumsi variabel lain tetap. Menurut Krugman et al., (2018) jarak antara dua negara mencerminkan biaya transportasi. Peningkatan jarak ekonomi menyebabkan peningkatan biaya transportasi yang diperlukan dalam kegiatan perdagangan antar negara. Akibatnya, semakin besar jarak ekonomi suatu negara maka ekspor akan semakin berkurang karena untuk meningkatkan ekspornya diperlukan biaya yang lebih besar.

Nilai koefisien variabel REER sebesar -0,7668. Tanda negatif pada koefisien menunjukkan hasil penelitian yang sesuai dengan hipotesis penelitian. Apabila terjadi peningkatan REER sebesar satu persen maka volume ekspor udang Indonesia berkurang 0,7668 persen dengan asumsi variabel lain tetap. Hal ini disebabkan oleh REER yang lebih tinggi akan memberikan indikasi rendahnya harga produk domestik (negara tujuan) relatif terhadap asing (Indonesia), karena dengan mata uang yang sama memberikan jumlah mata uang domestik yang lebih banyak. Sehingga, permintaan udang Indonesia akan menurun.

Variabel PDB ADHK negara tujuan berpengaruh positif tidak signifikan terhadap volume ekspor udang Indonesia ke 8 negara tujuan terbesar. Koefisien sebesar 0,011 berarti bahwa setiap terjadi kenaikan satu persen PDB ADHK negara tujuan maka volume ekspor udang Indonesia bertambah sebesar 0,011 persen dengan asumsi variabel lain tetap. Hasil estimasi tersebut sesuai hipotesis penelitian yang menyatakan bahwa PDB ADHK negara tujuan berpengaruh positif terhadap volume ekspor udang Indonesia. Hal ini sejalan dengan penelitian yang dilakukan oleh Ashari et al., (2016), Mitayani (2018), dan Wahyudi et al. (2019). Kenaikan PDB ADHK negara tujuan menunjukkan adanya kenaikan kemampuan daya beli negara tersebut. Akibatnya, permintaan udang Indonesia di negara tersebut akan meningkat.

Variabel populasi berpengaruh positif dengan nilai koefisien sebesar 0,1985. Nilai 0,1985 berarti bahwa setiap ada peningkatan satu persen populasi negara tujuan maka volume ekspor udang Indonesia akan bertambah sebesar 0,1985 persen dengan asumsi variabel lain konstan. Peningkatan populasi suatu negara memengaruhi jumlah perdagangan suatu komoditas dari sisi permintaan maupun penawaran. Meningkatnya jumlah populasi berdampak akan meningkatkan jumlah permintaan akan suatu komoditi tertentu (Salvatore, 2013).

Berikut adalah komponen cross section error (efek individu) pada model fixed effect with SUR:

Tabel 3. Efek individu pada model fixed effect with SUR

\begin{tabular}{cc}
\hline Negara & Koefisien \\
\hline Amerika Serikat & 2,6180 \\
Belanda & $-0,0976$ \\
Britania Raya & 0,3141 \\
Cina & 0,8182 \\
Jepang & 1,2815 \\
Malaysia & $-0,9929$ \\
Singapura & $-3,1084$ \\
Thailand & $-0,8329$ \\
\hline
\end{tabular}

Berdasarkan Tabel 3 dapat diketahui bahwa nilai efek individu tertinggi dimiliki oleh negara Amerika Serikat yaitu sebesar 2,6180 persen. Hal tersebut berarti bahwa ketika semua variabel bebas pada setiap individu tetap, peningkatan rata-rata volume ekspor udang Indonesia paling besar adalah ke negara Amerika Serikat. Hal tersebut sesuai dengan keadaan sesungguhnya, di mana ekspor udang Indonesia paling banyak diserap oleh Amerika Serikat. Sedangkan nilai efek individu terendah dimilik oleh negara Singapura yaitu sebesar -3,1084 persen. Hal tersebut bermakna bahwa ketika semua variabel independen pada setiap individu konstan, peningkatan rata-rata volume ekspor udang Indonesia paling rendah ke Singapura.

\section{KESIMPULAN}

Berdasarkan uraian hasil dan pembahasan dapat disimpulkan bahwa selama periode penelitian perkembangan ekspor udang Indonesia ke delapan negara tujuan terbesar memiliki tren positif. Ekspor udang Indonesia paling banyak diserap oleh Amerika Serikat. Daya saing udang Indonesia tahun 2012-2019 ke Amerika Serikat, Jepang, Cina, Malaysia, belanda, Britania Raya, dan Singapura di atas rata-rata dunia. Sedangkan daya saing ekspor udang Indonesia ke Thailand masih di bawah rata-rata dunia. Variabel harga ekspor riil, jarak ekonomi, dan REER berpengaruh terhadap volume ekspor udang Indonesia secara negatif 
signifikan. Sedangkan PDB ADHK dan jumlah populasi negara tujuan memengaruhi volume ekspor udang Indonesia ke delapan negara tujuan terbesar secara positif tidak signifikan.

\section{DAFTAR PUSTAKA}

Ashari, U., Sahara, S., \& Hartoyo, S. (2016). Daya saing udang segar dan udang beku Indonesia di negara tujuan ekspor utama. Jurnal Manajemen \& Agribisnis, 13(1), 1.

Badan Pusat Statistik (n.d.). Tabel Dinamis. Retrieved August 22, 2021, from https://www.bps.go.id/

Baltagi, B. (2011). Econometrics (5th ed.). John Wiley \& Sons.

Bappenas. (2009). Penyebab dan Dampak Krisis Keuangan Global.

Britannica, T. E. of E. (2004). Shrimp. In Encyclopedia Britannica. Encyclopedia Britannica. 9 Mei 2021. https://www.britannica.com/animal/shrimp-crustacean

CEPII. (n.d.). CEPII - GeoDist. Retrieved August 22, 2021, from http://www.cepii.fr/CEPII/en/bdd_modele/presentation.asp?id=6

Comtrade, U. (n.d.). UN Comtrade | International Trade Statistics Database. Retrieved June 22, 2021, from https://comtrade.un.org/

Greene, W. H. (2012). Econometric Analysis (8th ed.). Pearson.

Gujarati, D. N., \& Porter, D. C. (2009). Basic Econometrics (5th ed.). McGrawHill International Edition.

Handoyo. (27 November 2013). RI Pulangkan Udang Asal Malaysia. 8 Mei 2021 https://ekonomi.kompas.com/read/2013/11/27/0802063/RI?page=all\#page2

IMF. (2019). Real Effective Exchange Rate (REER). 5 Juni 2021. https://datahelp.imf.org/knowledgebase/articles/537472-what-is-real-effective-exchange-rate-reer

Juanda, B. (2009). Ekonometrika: Pemodelan dan Pendugaan. IPB Pres.

Kementrian Kelautan dan Perikanan. (n.d.). Statistik KKP. Retrieved August 22, 2021, from https://statistik.kkp.go.id/home.php

Kementrian Perdagangan Republik Indonesia. (n.d.). RCA. Retrieved August 22, 2021, from https://www.kemendag.go.id/addon/rca/index.php?isi=1

KKP. (2018). Buku Pintar Kelautan dan Perikanan. Pusat Data, Statistik, dan Informasi.

Krugman, P., Melitz, M., \& Obstfeld, M. (2018). International Economics: Theory and Policy (11th ed.). Pearson.

Li, K., Song, L., \& Zhao, X. (2008). Component trade and China's global economic integration. China: Linking Markets for Growth, 71.

Mankiw, N. G. (2016). Macroeconomics (9th ed.). Worth.

Mankiw, N. G. (2017). Principles of Macroeconomics (8th ed.). Cengage Learning.

Mashari, S., Nurmalina, R., \& Suharno, S. (2019). Dinamika Daya Saing Ekspor Udang Beku Dan Olahan Indonesia Di Pasar Internasional. Jurnal Agribisnis Indonesia (Journal of Indonesian Agribusiness), 7(1), $37-52$.

Mitayani, W. E. (2018). Determinan Permintaan Udang Indonesia di Lima Negara Tujuan Ekspor Utama di Asia (Jepang, Hong Kong, Tiongkok, Singapura, Malaysia). Universitas Islam Negeri Sunan Kalijaga.

Pindyck, R. S., \& Rubinfeld, D. L. (2013). Microeconomics (8th ed.). USA: Pearson Education.

Salvatore, D. (2013). International Economics (11th ed.). Wiley.

Teitelbaum, M. S. (2020). Population. In Encyclopedia Britannica. Encyclopedia Britannica. 10 Mei 2021. https://www.britannica.com/science/population-biology-and-anthropology

Wahyudi, A. F., Haryadi, J., \& Rosdiana, A. (2019). Analisis Daya Saing Udang Indonesia di Pasar Ekspor. Forum Agribisnis (Agribusiness Forum), 9(1), 1-16.

Walpole, R. E., Myers, R. H., Myers, S. L., \& Ye, K. (2016). Probability and statistics for engineers and scientists (9th ed., Vol. 5). Pearson Education Limited.

World Bank. (n.d.). World Bank Open Data. Retrieved August 22, 2021, from https://data.worldbank.org/ 